\title{
Evaluation of policy in the vocational education system revitalization in Indonesia: Examining the teaching factory radiness of industry
}

\author{
Bernadetta Quinta Pradipta * 1, Fajar Bambang Hirawan ${ }^{2}$, Safendrri Komara Ragamustari ${ }^{1}$ \\ ${ }^{1}$ Master in Public Policy, Sekolah Tinggi Kepemerintahan dan Kebijakan Publik. \\ Jl. Anyar, Hambalang, Citeureup, Sentul, Bogor, Jawa Barat 16810, Indonesia. \\ ${ }^{2}$ Centre for Strategic and International Studies (Indonesia). \\ Gedung Pakarti Centre, Jl. Tanah Abang III No. 23-27, Jakarta 10160, Indonesia. \\ * Corresponding Author. Email: b.pradipta@sgpp.ac.id
}

\section{ARTICLE INFO}

\section{Article History}

Received:

12 January 2021;

Revised:

18 February 2021;

Accepted:

26 February 2021

Available online:

18 August 2021

\section{Keywords}

Industry readiness;

Policy evaluation;

Revitalization;

Teaching factory;

Vocational education

\begin{abstract}
A future forecast for 2030-2040 predicts that Indonesia will face a demographic bonus, in which the productive aging population is greater than the unproductive age population. Graduates are expected to compete for a job on the national and international levels. It is a challenge where the Indonesian government began to enforce revitalization towards industries to collaborate with schools, and industries are expected to contribute to the implementation of the teaching factory, as both can contribute a mutual advantage in the long run. This research aims to illustrate the Indonesian government's progress, starting from 2016-2019, on revitalizing the vocational education system. This research highlights a qualitative research approach with a micro-level case study, using the teaching factory implementation parameter in VHS Suryacipta to find industries' readiness based on their perspectives, expectations, and challenges. The findings indicate the government effort has successfully improved the revitalization program. However, it still lacks field implementation. VHS Suryacipta still lacks collaboration follow-up with the industries, and the social mores of Karawang traditional society be the main factor behind the high unemployment rate. Other factors are the industries' capacity for employment, confidentiality aspect, misperception between industries and local government. Industries find difficulties matching with government agenda, which revealed that industries are not ready for collaboration.
\end{abstract}

This is an open access article under the CC-BY-SA license.

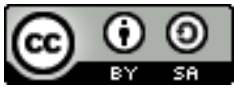

How to cite:

Pradipta, B. Q., Hirawan, F. B., \& Ragamustari, S. K. (2021). Evaluation of policy in the vocational education system revitalization in Indonesia: Examining the teaching factory radiness of industry. Jurnal Pendidikan Vokasi, 11(1), 68-77. https://doi.org/10.21831/jpv.v11i1.37693

\section{INTRODUCTION}

Industry 4.0 is one of Indonesia's challenges to utilize human resources in the industrial field. It is undeniable that the number of Indonesian workforces has reached 133.94 million people, or half of the population in Indonesia (Badan Pusat Statistik Republik Indonesia, 2018). Besides, in 20302040 , Indonesia will face a demographic bonus in which the number of the productive age population (aged 15-64 years) is greater than the unproductive age population (aged under 15 and above 64 years). In 2019, it was recorded that there were 7.05 million unemployment and $10.42 \%$ dominated by vocational high school graduates (Ulya, 2019).

Indonesia eventually established the program towards Rencana Pembangunan Jangka Menengah Nasional 2020-2024. It is concerned about the needs of a competent, creative, and 
innovative, and adaptive workforce to be optimally fulfilled. It is a challenge where the proportion of Indonesia's competitiveness only reached $39.57 \%$. Lack of information about job opportunities and lower industry participation can affect the mismatch between vocational education and vocational training. This mismatch in Indonesia likely happens because the government has no clear understanding of the vocational school competency and the industry. The quality has not yet been supported by facilities, qualified lecturers, adequate internships, and limited vocational education certification. The other aspect is the lack of mastering soft skills of a foreign language, critical thinking, analysis, leadership, negotiation, and teamwork. In addition, if the students are active and empowered, they can become qualified workers (Schallock et al., 2018). Currently, the Indonesian government is targeting vocational training with a dual TVET system, which can emphasize practice-based skills and internships in industry and contribute to incentive systems, or regulations to encourage industry role in vocational education and training (Kementerian Perencanaan Pembangunan Nasional Republik Indonesia, 2020).

However, not all vocational schools in Indonesia have implemented revitalization effectively. The government made various efforts to align schools with industry, including establishing cooperation of 100 vocational schools with companies. The cooperation not only happened because of government enforcement but needed both party initiative for the realization. The Coordinating Minister for the Economy, Cabinet Minister during 2014-2019, Joko Widodo's administration, Darmin Nasution, stated: "Indonesia government still finds difficulties in building synergies between education and industry even various efforts have been carried out the last 20 years unable to produce any results" (Koran Sindo, 2018).

It is a challenge for vocational education and companies in the industry to achieve synergies. They do not understand each other's needs, have no socialization, and have no technical guidance (Widiyanti et al., 2019). Especially for the company mindset, vocational students can not be equated with general employees but must understand the limits on what they are pursuing as students. On the other hand, every company has to realize that it took time to build a corporate culture for the students to adjust themselves in training. In implementing the teaching factory, the company must understand each school's current conditions, including the knowledge of school profiles, curriculum, and whether competencies already match the industry. The success of the teaching factory, in the end, will contribute to the occupational readiness in dealing with real-life work situations (Khoiron, 2016) and practically students' tendency to excel and high self-confidence (Amar et al., 2015).

In 2019, the open unemployment rate (TPT) for vocational graduates had declined $10.42 \%$ over the past two years but had the highest percentage compared to other graduate levels (primary schools, secondary schools, high schools, diplomas, and university). Due to a lack of suitability in terms of expertise required in the labor market (Badan Pusat Statistik Republik Indonesia, 2019), especially in the local region in Karawang, the number of the unemployment rate is $11.51 \%$. The majority are high school and vocational education by $43 \%$ (Iryanti, 2017). The leading sectors in Karawang are manufacturing, agriculture, tourism, and hospitality. The number of Vocational Education and Special Training Institutions (LPK) which offer training is limited, and there is no offer of expertise in agriculture and plantations. The utilization of facilities and infrastructure of the Vocational Training Body/BLK has not been maximally installed (Iryanti, 2017).

In the Karawang regency, the labor force participation rate (TPAK) is decreasing from 64,77 (2018) to 63,62 (2019) (Badan Pusat Statistik Kabupaten Karawang, 2020) and from 28,000 high school or vocational graduates, only 6,000-7,000 continue to higher education. Simultaneously, labor absorption in a year is only 5,000 people (Dinas Tenaga Kerja dan Transmigrasi Kabupaten Karawang Republik Indonesia, 2020). The condition is problematic as the access to work training is limited, and workers find it difficult to compete with other job applicants, especially outside Karawang (Janoka, 2017). This condition is important to examine starting with a question of "What is the level of progress of Indonesia's vocational education system, especially for the Ministry of Education and Culture of the Republic of Indonesia, in implementing the revitalization policy of the teaching factory in 2016-2019?" and second, "What is the level of the four companies' readiness in cooperating with VHS Suryacipta to implement the TEFA (Teaching Factory) method?"

This research aims to analyze and review the progress of implementing vocational education policy in Indonesia based on Presidential Instruction of the Republic of Indonesia Number 9 of 2016, 
realizing national education development goals (Presiden Republik Indonesia, 2016). Continuing the Instruction of the President of the Republic of Indonesia, it is hoped that the curriculum can be aligned with link and match as a framework for school and industry thinking.

Furthermore, the research that took place at VHS Suryacipta will determine whether the school has implemented the teaching factory optimally and analyze the different perspectives between the school and companies. It is important to research which data results on the company's perspective will be used as an evaluation to improve the Karawang regional government to not only focus on the school's perspective in terms of link and match.

\section{RESEARCH METHOD}

This study uses a qualitative research approach with a case study. Qualitative research is a method of investigating and interpreting the nature of social or humanitarian issues assigned to many individuals or groups of people (Creswell, 2013). Therefore, this research method will produce descriptive data that describe the government's progress in revitalizing vocational education nationally that links to the Presidential Instruction in 2016. According to Cresswell, five primary qualitative research approaches include narrative research, phenomenology, grounded research, ethnology, and case study (Creswell, 2013). Case study research as "The study of a case within a real-life contemporary context or setting" (Yin, 2009) and emphasize a critical element "In defining a case that can be bounded or described within certain parameters such as a specific place and time" (Stake \& Nickens, 2005). Related to the teaching factory conducted in VHS Suryacipta, the single instrumental case study research is more appropriate to use as it describes the implementation of the teaching factory and industries' readiness. Using GIZ's seven indicators, VHS Suryacipta can be examined in management, laboratory, training, marketing, product or service, human resources, and industry relations. A research design was carried out to make it easier to conduct research, which can be seen in Figure 1.

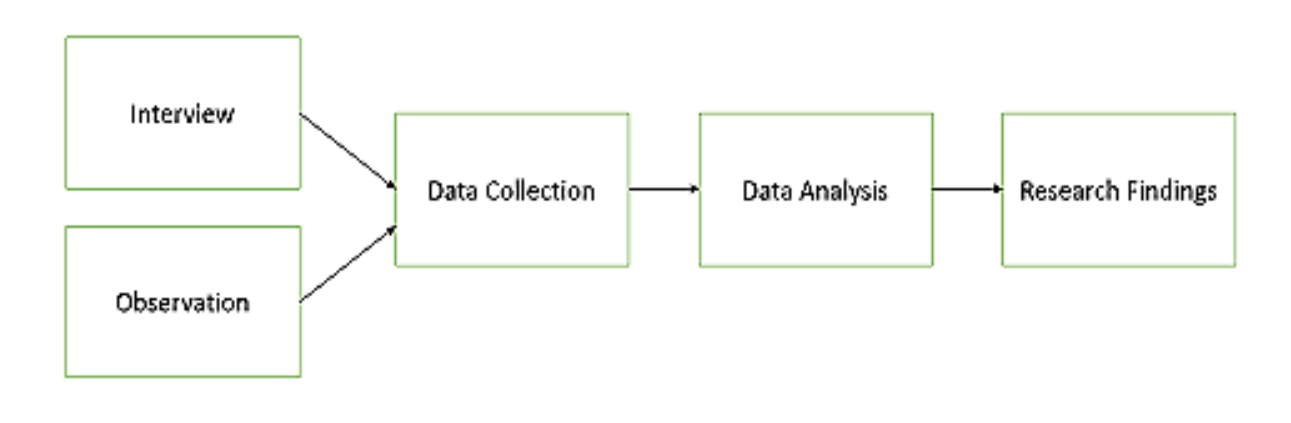

Figure 1. Research Design

The object studied in this study was VHS Suryacipta in Karawang regency regarding implementing the teaching factory and the industrial readiness in collaboration with the institution. The time of this research was carried out starting in March 2020. Participants involved in this research were the principal of VHS Suryacipta and four employee representatives from each company. Due to limitations in visiting each company, the researcher conducted online interviews starting in June with a duration of 30 minutes. This snowball sampling originated from the link of VHS Suryacipta acquaintances who have experience managing student internships in the industry.

At this stage, the researcher conducted an observation with a 2-day visit at VHS Suryacipta and the Research and Development Center. Furthermore, semi-structured interviews were managed by holding questions and answers directly to the participants without strictly following a formalized list of questions. The answer will not be answered with "yes" or "no." There will be follow-up questions from their answer. The secondary data were also obtained through journals, government websites, books, link and match programs of the Ministry of Education from the year 2016 until 2019, according to the Presidential Instruction concerning the Revitalization of Vocational Schools to Improve the Quality and Competitiveness of Human Resources in Indonesia. 
Data analysis of this research is using descriptive analysis. After obtaining the primary data from observation and interview, the researcher combined all the findings with the support from secondary data. The techniques of evaluation are using: 1.) Data Reduction: The process of selecting, abstracting, and informing rough data from the field. The results of interviews and observations were reduced to find out the data following the study's focus and problem; 2.) Presentation of Data: Data are categorized and presented in tables and graphs, which are grouped according to the aspects studied; and 3.) Verification and Affirmations of Conclusions: Concluding the form of interpretation activities that find the data's meanings must be tested for the truth and suitability of their validity.

\section{RESULT AND DISCUSSION}

\section{Result}

Ministry of Education and Culture Strategic Plan 2014-2019

In improving vocational high school programs' work and guidance, the Directorate of Vocational Education, the Provincial Education Office, and other involved parties formulated a Strategic Plan (RENSTRA) for the 2014-2019 period. Strategic planning is an integral part of a government institution's performance accountability system (SAKIP) and is used as a data source for work evaluation. One of the policies in the development of vocational education is; Improving the quality and relevance of learning-oriented to the formation of character to the industrial world's needs (Direktorat Jenderal Penguatan Riset dan Pengembangan Republik Indonesia, 2019). The development of the performance of the Directorate of Vocational High Schools of the Republic of Indonesia in 2016-2019 can be seen in Figure 2.

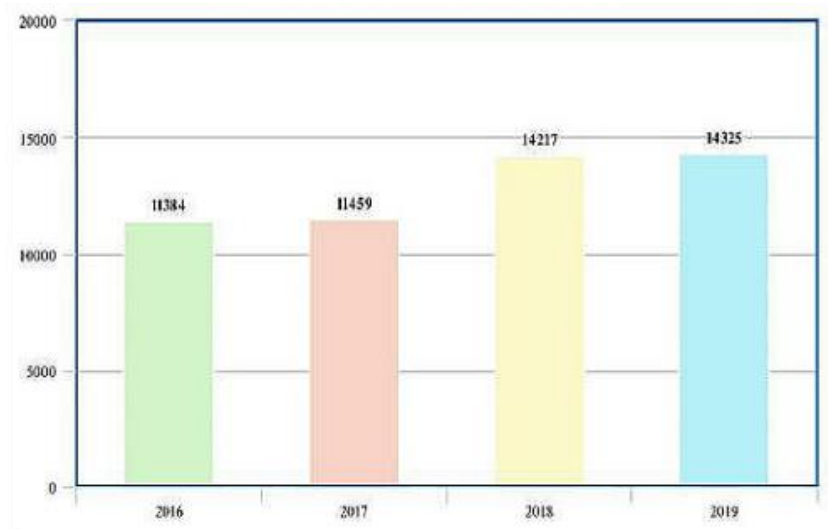

Figure 2. Number of Vocational High Schools that Implement the Curriculum

This progress was due to vocational programs that use a dual system program and vocational programs that compose independent vocational questions or non-national exams. However, there are obstacles in its achievement because the vocational high school activities implementing dual system programs have time adjustment constraints. In contrast, the vocational program that compiles questions by the effective teacher still has difficulties in uploading files to the application. Not all schools can develop good quality questions in this program because it takes time to review (Direktorat Jenderal Penguatan Riset dan Pengembangan Republik Indonesia, 2019). In 2019, the Directorate of Vocational High Schools of the Republic of Indonesia had targeted 500 schools to develop teaching factories, while this trend has increased from 2016-2019, as shown in Figure 3.

Achievement of this indicator has reached 100\% development throughout Indonesia. However, the obstacle faced is that not all supervisors, teachers, and school principals understand the technical guidelines for activities that affect implementation quality. Second, the limited implementation time, especially in schools that receive assistance following the technology guidance at the final stage, affects the teaching factory's quality. Third, the distribution of assistance in 
conjunction with the condition of renovated schools or new buildings affects the quality of teaching factory implementation because of its physical output. Thus, the job fair provided by vocational schools has increased from year to year. Not to mention the addition of several job fairs (BKK) owned by the Ministry of Labor so students can widely access that information about work. In 2019, 5,690 schools participated in the BKK program, or $40 \%$ of the population (Direktorat Jenderal Penguatan Riset dan Pengembangan Republik Indonesia, 2019). The number of Vocational High Schools that organize job fairs/BKK Services can be seen in Figure 4.

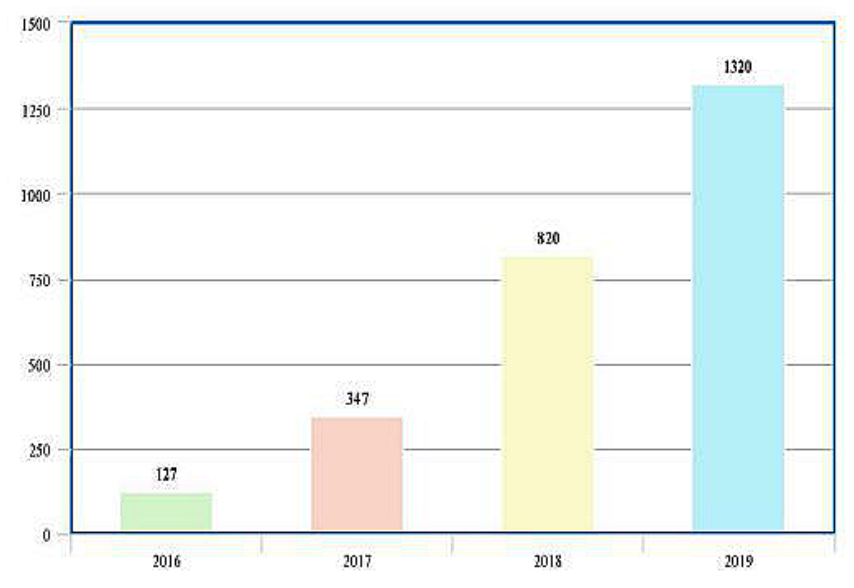

Figure 3. Number of Vocational High Schools that Implement the Teaching Factory/Technopark

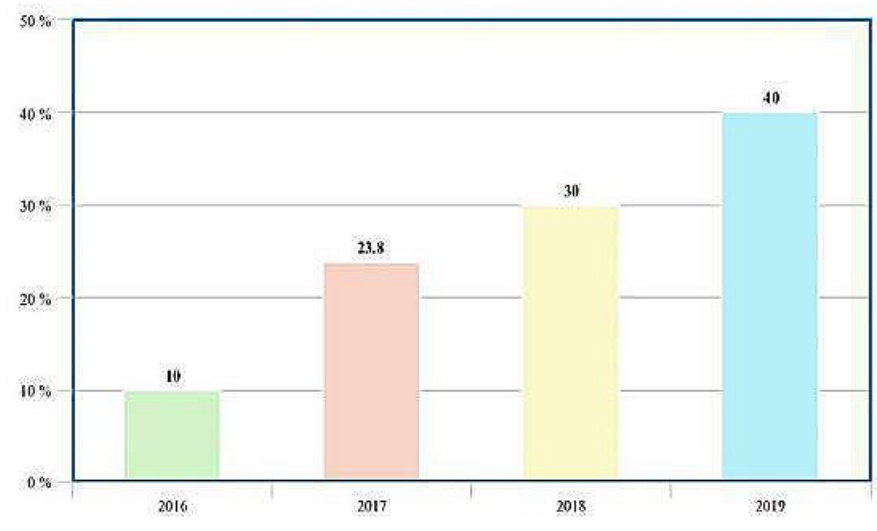

Figure 4. Number of Vocational High Schools that Provide Job Fair/BKK Service

Schools that collaborate with DUDI and other institutions have reached up to 11,250 schools due to successful programs such as industry-based or regional excellence programs, the vocational high school in the national industrial area, and vocational high schools that carry out industrial classes. The average results of this form of cooperation are part of the teaching factory, which is an apprenticeship in the industry to get an education by DUDI. The obstacle in 2019 was that certain skills in schools were challenging to find DUDI that can be used as a partner (Direktorat Jenderal Penguatan Riset dan Pengembangan Republik Indonesia, 2019).

Interview Findings in VHS Suryaciota

Based on an interview conducted with the Principal of VHS Suryacipta, Mr. Wahyu Cahyo Purnama, explained that seven teaching factory indicators affect the progress of VHS Suryacipta in implementing GIZ. These factors are: 1.) Marketing and promotions; 2.) Training; 3.) Industry relations; 4.) Human resources; 5.) Products and services; 6.) Laboratory; and 7.) Management. 


\section{Marketing and Promotions}

VHS Suryacipta has a marketing strategy through advanced apprenticeship programs to get students closer to the industry. Wahyu said in the first year, VHS Suryacipta had made bicycles, and students from dormitories used bicycles to schools. By using their product, it can attract employees in the Suryacipta industrial area. The promotion is also carried out well through parental assistance in parent social groups. However, VHS Suryacipta experienced challenges caused by the community in Karawang Regency, such as middle schools often practicing students' bribery to vocational schools to be accepted. In addition, the social mores of Karawang students who live in the periphery. VHS Suryacipta manages these problems by providing entrance-test psychological tests rather than focusing on students' academic reports.

\section{Training}

The students are familiar with corporate culture and entrepreneurship. Understanding entrepreneurship will give them ideas in work planning, such as product price, cost, and profit (Siswanto, 2011). VHS Suryacipta students studied safety in working and time discipline. Their learning implementation Plan or RPP already followed the curriculum.

\section{Industry Relations}

According to Purnama (Suryacipta Vocational School Principal), currently, some industries join in cooperation. However, the implementation is ongoing because the school and the companies discuss transfer technology, internship, project work, and class participation. Regarding cooperation with industries that will receive tax incentives, there is currently no incentive because, according to him, tax incentives were still difficult to process.

\section{Human Resources}

From a business perspective, human resources can be found in the number of students in the provision of vocational facilities. The maximum limit for one class is 24 people. In the National Accreditation Board for Higher Education or National Accreditation Board for Higher Education of the Republic of Indonesia regulations, there are at least 20 students and a maximum of 30 students. However, VHS Suryacipta limits 24 children to be divided into several competencies they take. The National Accreditation Board for Higher Education of the Republic of Indonesia guidelines state that teacher education costs must be paid, but most of their education was still unsupported with technical knowledge for those with vocational backgrounds. Therefore, VHS Suryacipta took diploma instructors and not teachers, knowing that instructors have more knowledge about skills transfer.

\section{Products and Services}

VHS Suryacipta products are electric bicycles, cutting tools, alarms for homes and vehicles, benches, and lab equipment. The current 10th-grade students will soon learn to prepare products, delivery targets, and quality in grades 11 and 12 . The implementation of the teaching factory in VHS Suryacipta is still gradual and basic. Therefore, the school is expecting industries to transfer technology.

\section{Laboratory}

VHS Suryacipta has two machines in the workshop and plans to have six machines for 24 students. The laboratory will increase as needed. Maintenance and machine calibration are still using basic machines.

\section{Management}

In the organizational structure of VHS Suryacipta, there is a maximum of one principal and two vice principals, but currently, there is no vice-principal. A good organizational structure job description is still gradual because only one department is managed. The Suryacipta Foundation fully supports the remaining management and structurally only needs to fill in the people on organization slots. From the leadership aspects in integrating with the teaching factory, the quality objectives and the understanding of quality have been integrated, but school documents are still incomplete. 
Industries Challanges and Perspective

Fukuyama Giken Indonesia

Currently, the cooperation with VHS Suryacipta was in terms of student's internships in the 3rd semesters and the 4th semester, with the expectation that students will understand the corporate culture. An interview conducted with Sri Lestari, Administrative Assistant Manager from Fukuyama Giken Indonesia, stated that vocational students are the main priority in the absorption of company human resources at the operator level. According to Lestari, "The biggest challenge to the company is the attitude and personality of the students because that knowledge is still lacking." In addition to that, for her, "Most vocational and university graduates are only skilled in theory and weak in practice." Sri Lestari suggested that the Indonesian government have an easy or coherent policy in industrial work practices.

\section{Nipro Indonesia Jaya}

Nipro has not collaborated with VHS Suryacipta. Instead, Nipro collaborated with other vocational high schools. Nipro hopes to get prospective employees but can not guarantee that all students can be accepted at Nipro because there will be a selection process. The results of an interview conducted with Mrs. Evi Dwitya Wijaya, Human Resource Supervisor of Nipro Indonesia Jaya, stated that "Nipro can develop a curriculum with schools based on company assessments without going through BLK, but it is complicated because Nipro has other schedules and priorities."

Regarding tax incentives, things like this have been implemented in other companies, but for Nipro, it has not started yet. Mrs. Evi Dwitya Wijaya also suggested that the government should be more active in supporting schools to collaborate with industry because Nipro Indonesia Jaya only accepts students who have expertise in using computers and administrative skills to input data. In addition, the potential for students to be recruited as employees is as high as $80 \%$ of students do not have a bad track record. There need to be guaranteed from the central, local government, and schools to convince companies that students can maintain company confidentiality.

\section{Nestle Indonesia}

Mr. Kesit Kanigoro, External Relations and CSV Manager at Nestle Indonesia, stated that VHS Suryacipta had requested Nestle's input regarding the curriculum's suitability with the industry. The industry's character in Nestle companies is different from other companies, which might be an obstacle in the absorption of intern students due to Nestle company using more machines than the number of employees. Unless there are projects, Nestle can provide opportunities for students to work. The main needs of Nestle in the absorption of human resources are attitude, discipline, and skill. However, Nestle faced some challenges such as social mores of the Karawang traditional society, workers often resign, companies are pressured by the local government, Nestle's vacancies are not opened every year, and interference from unpleasant individuals when a person is applying for a job. There is also a different perception during the socialization of companies and Karawang regional government, in which Karawang regional government thinks that all students must be accepted in the companies, even though this should not force the companies.

\section{Indoplat Perkasa Purnama}

Joko Sriyanto, Human Resource Staff Indoplat Perkasa Purnama, said that Indoplat has no further progress and discussion about the internship with VHS Suryacipta. Indoplat preferred internships after students graduated from high school. Aspects needed for students during the internship are using Japanese philosophy seiri (sort), seiton (set in order), seiso (shine), seiketsu (standardize), and shitsuke (sustain). Indoplat has challenges such as qualified students from reputable schools are mostly recruited by big companies, which other medium and small companies have no opportunity. Thus, extra training for students if the students have no experience using the tools or the school has not been synchronized with the industry. He mentioned that the social mores of the Karawang traditional society are also a problem. Workers often resign from one job to another. 


\section{Discussions}

From the research findings, the government progress from 2016-2019 has successfully improved vocational education. However, since the 2013 curriculum has followed DUDI, there were obstacles in time adjustment for vocational high school activities implementing dual system programs. Some schools have difficulties developing good-quality exam questions, and effective teachers find it hard to use the application. Thus, the limited implementation time for schools to receive assistance or the renovated school's condition affects the teaching factory's quality. Besides, some schools with certain skills find it hard to get industry partners.

However, the government results can not be fully claimed as it was successful compared to the reality in VHS Suryacipta and companies around Karawang regency. Not all implementation aspects were done smoothly because VHS Suryacipta still had basic machines, and collaboration with industries lacked follow-up.

From all interviews, it is concluded that all industries have similarities in their unreadiness in collaboration with vocational schools because each company has its procedure and different expectations in accepting intern students, such as reasons of industry limitation in accepting numbers of workers, confidentiality aspect, industry hesitation due to different perceptions between the regional government and ministry, deceitfulness from individuals, misperception about link and match and social mores from Karawang traditional society. However, it still can be maintained to implement link and match. An exception like Nestle, for instance, already used automatic machines to replace their workers, which is more challenging in implementing the link and match in comparison with the other three companies.

\section{CONCLUSION}

The result showed how industries seem unsure about fulfilling school expectations because they have limited demand from human resources and access quality. Furthermore, there are inadequacies in realizing activities in the field, such as the lack of control over program implementation from the monitoring side, especially in the Karawang area. Monitoring and evaluation must be carried out starting from the Karawang local government level so that the implementation of the policies that have been determined can be right on target.

For the evaluation in VHS Suryacipta, the school should set clear objectives in collaboration with industries. If necessary, the school can invite industry visits as a part of the teaching factory. Better if the school and other vocational high schools developed a joint industry curriculum and assessment scheme to ensure facilities are aligned with industry standards and employ industry practitioners in school. In addition, increasing the school's effectiveness and industrial alignment can involve the Karawang government's supervision. Second, at the regional level of implementation, it is necessary to establish a work unit in the industrial service tasked with gathering input and recommendations from industry related to industrial-based development models. The industry can add another department that focuses on handling vocational high schools.

Third, coordination between government institutions and disseminating any program or policy changes are significant so that implementers can understand that the program can achieve its targets. Including the provision of tax incentives must be more clearly disseminated technically so that the industry is more interested and obtains benefits. Fourth, the development of link and match should focus on big industries and use SMEs as another alternative to facilitate students. Because the potential of SMEs can optimize the absorption of the workforce. SMEs can provide attention according to local wisdom that can be integrated. Last, each local government must provide a vocational high school database for every vocational graduate to make it easier for the industry to find a workforce. This database can be completed with certificates and academic reports.

\section{REFERENCES}

Amar, A. F., Hidayat, D., \& Suherman, A. (2015). Penerapan model pembelajaran teaching factory 6 langkah (Model TF-6M) untuk meningkatkan motivasi berprestasi siswa di SMK. 
Indonesian Journal of Science and Technology, 2(2), 189-198. https://doi.org/10.17509/jmee.v2i2.1479

Badan Pusat Statistik Kabupaten Karawang. (2020). TPAK dan TPT Kabupaten Karawang 2013 $2020 \quad$ (persen). Karawangkab.Bps.Go.Id. https://karawangkab.bps.go.id/dynamictable/2018/03/06/27/tpak-dan-tpt-kabupatenkarawang-2013---2019-persen-.html

Badan Pusat Statistik Republik Indonesia. (2018). Februari 2018: Tingkat Pengangguran Terbuka (TPT) sebesar 5,13 persen, rata-rata upah buruh per bulan sebesar 2,65 juta rupiah. Bps.Go.Id. https://www.bps.go.id/pressrelease/2018/05/07/1484/februari-2018--tingkatpengangguran-terbuka--tpt--sebesar-5-13-persen--rata-rata-upah-buruh-per-bulan-sebesar2-65-juta-rupiah.html

Badan Pusat Statistik Republik Indonesia. (2019). Keadaan angkatan kerja di Indonesia Februari 2019 (Subdirektorat Statistik Ketenagakerjaan Republik Indonesia (ed.)). BPS RI. https://www.bps.go.id/publication/2019/05/31/a96ce41f72e59d5dfb1cad9f/keadaanangkatan-kerja-di-indonesia-februari-2019.html

Creswell, J. W. (2013). Qualitative inquiry and research design: Choosing among five approaches (3rd ed.). SAGE Publications, Inc.

Dinas Tenaga Kerja dan Transmigrasi Kabupaten Karawang Republik Indonesia. (2020). Disnakertrans: Kab. Karawang. Karawangkab.Go.Id. https://www.karawangkab.go.id/dokumen/dinas-tenaga-kerja-dan-transmigrasi

Direktorat Jenderal Penguatan Riset dan Pengembangan Republik Indonesia. (2019). Rencana Strategis Direktorat Pembinaan SMK 2015-2019. Kementerian Riset, Teknologi, dan Pendidikan Tinggi Republik Indonesia.

Iryanti, R. (2017). Education \& skill mismatch di Indonesia: Kondisi saat ini dan kebijakan pemerintah. Kementerian Perencanaan Pembangunan Nasional Republik Indonesia. http://sdgcenter.unpad.ac.id/wp-content/uploads/2017/08/Rahma-Iryanti-Education-SkillMismatch-di-Indonesia-Kondisi-Saat-ini-dan-Kebijakan-Pemerintah.pdf

Janoka, J. (2017, October 6). Angka pengangguran di Karawang meningkat. Logikanews.Com. https://logikanews.com/angka-pengangguran-di-karawang-meningkat/

Kementerian Perencanaan Pembangunan Nasional Republik Indonesia. (2020). Rencangan teknokratik: Rencana pembangunan jangka menengah nasional 2020-2024. https://www.bappenas.go.id/files/rpjmn/Narasi RPJMN IV 2020-2024_Revisi 28 Juni 2019.pdf

Koran Sindo. (2018, July 25). Sekolah dan industri masih sulit sinergi. SINDOnews.Com. https://nasional.sindonews.com/berita/1324749/15/sekolah-dan-industri-masih-sulit-sinergi

Presiden Republik Indonesia. (2016). Instruksi Presiden Republik Indonesia Nomor 9 Tahun 2016 tentang Revitalisasi Sekolah Menengah Kejuruan Dalam Rangka Peningkatan Kualitas dan Daya Saing Sumber Daya Manusia Indonesia.

Schallock, B., Rybski, C., Jochem, R., \& Kohl, H. (2018). Learning Factory for Industry 4.0 to provide future skills beyond technical training. Procedia Manufacturing, 23, 27-32. https://doi.org/10.1016/j.promfg.2018.03.156

Stake, J. E., \& Nickens, S. D. (2005). Adolescent girls' and boys' science peer relationships and perceptions of the possible self as scientist. Sex Roles, 52(1), 1-11. https://doi.org/10.1007/s11199-005-1189-4

Ulya, F. N. (2019, November 5). BPS: Pengangguran meningkat, lulusan SMK mendominasi. Kompas.Com. https://money.kompas.com/read/2019/11/05/155358926/bps-pengangguranmeningkat-lulusan-smk-mendominasi 
Widiyanti, W., Renita, R., Edy, D. L., \& Dianawati, R. (2019). Obstacles of implementing a teaching factory: An analysis in Vocational Secondary School. International Journal of Innovation, Creativity and Change, $8(1$ (Special Edition)), 361-376. https://www.ijicc.net/images/vol8iss1/8128_Widiyanti_2019_E_R.pdf

Yin, R. K. (2009). Case study research: Design and methods. In L. Bickman \& D. J. Rog (Eds.), Applied social research methods series v. 5 (4th ed.). SAGE Publications, Inc. 